\title{
Lethal skeletal dysplasia from targeted disruption of the parathyroid hormone-related peptide gene
}

\author{
Andrew C. Karaplis, ${ }^{1,6}$ Arne Luz, ${ }^{2}$ Julia Glowacki, ${ }^{3}$ Roderick T. Bronson, ${ }^{4}$ Victor L.J. Tybulewicz, ${ }^{5,7}$ \\ Henry M. Kronenberg, ${ }^{1,8}$ and Richard C. Mulligan ${ }^{5}$ \\ ${ }^{1}$ Endocrine Unit, Massachusetts General Hospital and Harvard Medical School, Boston, Massachusetts 02114 USA; ${ }^{2}$ Institut \\ für Pathologie, GSF München, 8042 Neuherberg, Germany; ${ }^{3}$ Orthopedic Research Laboratory, Department of Orthopedic \\ Surgery, Brigham and Women's Hospital and Harvard Medical School, Boston, Massachusetts 02115 USA; ${ }^{4}$ Department \\ of Pathology, Tufts University Schools of Medicine and Veterinary Medicine, Boston, Massachusetts 02111 USA; \\ ${ }^{5}$ Whitehead Institute for Biomedical Research, Nine Cambridge Center, Cambridge, Massachusetts 02142 and Department \\ of Biology, Massachusetts Institute of Technology, Cambridge, Massachusetts 02139 USA
}

The parathyroid hormone-related peptide (PTHrP) gene was disrupted in murine embryonic stem cells by homologous recombination, and the null allele was introduced into the mouse germ line. Mice homozygous for the PTHrP null mutation died postnatally, probably from asphyxia, and exhibited widespread abnormalities of endochondral bone development. Histological examination revealed a diminution of chondrocyte proliferation, associated with premature maturation of chondrocytes and accelerated bone formation. Analysis of earlier developmental stages revealed that disturbance in cartilage growth preceded abnormal endochondral bone formation. There were no morphological abnormalities apparent in other tissues. These results provide direct evidence implicating PTHrP in normal skeletal development and serve to emphasize its potential involvement in human osteochondrodysplasias.

[Key Words: PTHrP; gene targeting; fetal skeletal development; chondrodysplasia; chondrocyte differentiation]

Received October 15, 1993; revised version accepted December 9, 1993.

Parathyroid hormone-related peptide (PTHrP) was identified initially because of its production by tumors associated with humoral hypercalcemia of malignancy (for review, see Stewart et al. 1989). This common paraneoplastic syndrome is characterized by hypercalcemia and hypophosphatemia, biochemical abnormalities often associated with oversecretion of parathyroid hormone $(\mathrm{PTH})$, the major peptide regulator of calcium homeostasis. The similarity in biochemical abnormalities between oversecretion of PTH and humoral hypercalcemia of malignancy arises because PTHrP resembles PTH structurally in the amino-terminal region $(1-34)$ and functions, at least in part, by binding to the common, recently cloned PTH-PTHrP receptor that recognizes the 1-34 region of these molecules (Jüppner et al. 1988,1991; Abou-Samra et al. 1992).

The human PTHrP gene is a complex transcriptional unit. It comprises 9 exons (for review, see Martin et al. 1991), uses at least three promoters and, by alternate splicing, gives rise to three major isoforms of the mature

Present addresses: ${ }^{6}$ Department of Medicine, Division of Endocrinology, Sir Mortimer B. Davis-Jewish General Hospital, McGill University, Montréal, Québec, Canada H3T 1E2; 'National Institute for Medical Research, The Ridgeway, Mill Hill, London, NW7 1AA, UK

${ }^{8}$ Corresponding author. peptide, one of 139,141 , and 173 amino acids. The single transcript for rat (Thiede 1988; Yasuda et al. 1989) and mouse (Mangin et al. 1990) PTHrP encodes the 141-residue isoform (139 amino acids in the mouse, because of a 2-amino-acid deletion), whereas two chicken transcripts encode proteins of 139 and 141 amino acids. Human, rat, mouse, and chicken PTHrP share marked amino acid sequence identity throughout the amino terminal and midregion portions of the protein but diverge beyond residue 112 . The striking conservation of this protein sequence suggests that PTHrP must play an essential role in cellular biology.

Although initially discovered in malignancies, mRNA encoding PTHrP is also present in normal keratinocytes, central nervous system, endocrine pancreas, adrenal glands, gravid myometrium, distended urinary bladder, endothelial smooth muscle, and lactating mammary tissue (Martin et al. 1991). More recently, the PTHrP gene has been shown to be expressed in many fetal tissues in a temporally and spatially specific pattern (Moniz et al. 1990; Campos et al. 1991; Senior et al. 1991; Stolpe et al. 19931. From numerous studies, it would appear that PTHrP may act as a paracrine, autocrine and, at times, endocrine factor. Several important roles have been proposed for PTHrP, including control of tissue differentia- 
tion, neurotransmission, transplacental calcium transport, and smooth muscle relaxation (for review, see Martin et al. 1991).

In spite of this wealth of information, defining the function of PTHrP has been difficult, given that its synthesis and secretion are not limited to a specific tissue. To gain further insight into the physiologic role of PTHrP, we have disrupted this gene in murine embryonic stem (ES) cells by homologous recombination and have generated a mouse strain deficient in PTHrP. Mice homozygous for the mutated PTHrP gene die at birth, probably of asphyxia, and exhibit a multitude of skeletal deformities phenotypically consistent with a form of osteochondrodysplasia. These results suggest a critical role for PTHrP in the process of normal skeletal development.

\section{Results}

\section{Construction of the vector and targeted disruption} of PTHrP gene in ES cells

To clone the mouse PTHrP gene a probe was generated by PCR amplification of rat genomic DNA /done before the report of Mangin et al. (1990) on the cloning of the murine PTHrP gene] using primers derived from exon III (the homolog of mouse exon IV) sequences (Karaplis et al. 1990). Using this probe, a BALB/c mouse genomic library was screened, and three clones were isolated and plaque purified. One clone, $\lambda-18$, was used for construction of the targeting vector. This clone contained the murine PTHrP exon IV and V, encoding the mature 139amino-acid protein and the 3 -untranslated region.

To target the PTHrP gene, a sequence replacement vector was designed using the pPNT plasmid (Tybulewicz et al. 1991) and fragments of the cloned PTHrP gene isolated from $\lambda-18$ (Fig. 1a). Approximately $7 \mathrm{~kb}$ of PTHrP genomic DNA was used for the construction of this vector. A $3.5-\mathrm{kb}$ genomic fragment from sequences $5^{\prime}$ to exon IV and a $3.6-\mathrm{kb}$ SacI-BamHI fragment $3^{\prime}$ to exon IV were inserted into the XhoI and EcoRI sites of pPNT, respectively, to generate the targeting vector pPNT-PTHrP. A double crossing-over event would substitute the bacterial neomycin resistance gene $\left(n e O^{\mathrm{T}}\right)$ selectable marker for $1.2 \mathrm{~kb}$ of endogenous sequences (PstI-SacI) containing exon IV (Fig. Ib). Because this exon comprises nearly all of the coding region of the mature protein, the disruption would be predicted to result in a null allele. The presence of the polylinker sequence $3^{\prime}$ to the neo ${ }^{\mathrm{r}}$ gene also introduced a new EcoRI restriction site into the allele (Fig. la, b), thereby, allowing for detection of homologous recombination events with Southern blot analysis.

pPNT-PTHrP was linearized at the unique NotI site and introduced into $8 \times 10^{6}$ recipient D3 ES cells (Doetschman et al. 1985) by electroporation (final concentration, $30 \mu \mathrm{g} / \mathrm{ml}$ ). Enrichment for mutant ES cells with one damaged PTHrP allele was achieved using positivenegative selection (Capecchi 1989) with the drugs G418 and 1-[2-deoxy, 2-fluoro- $\beta$ - $D$-arabinofuranosyl $]-5$-iodou- racil (FIAU). The enrichment attributed to FIAU selection was $\sim 17$-fold (data not shown).

After selection, colonies resistant to both drugs were expanded clonally, and identification of clones with a disrupted PTHrP gene was accomplished by Southern blot analysis. Hybridization of an EcoRI digest from these clones with probe A (Fig. lb), located adjacent to the $3^{\prime}$ side of the homology region present in the targeting vector, showed the $>20$-kb fragment from the wildtype allele, as well as the expected $6.7-\mathrm{kb}$ fragment from the targeted PTHrP locus (Fig. 1c). Ninety-five doubly resistant clones were analyzed and six independent homologous integration events were identified. Thus, homologous recombination was observed in $6 \%$ of all doubly resistant clones. The targeted clones were analyzed further by Southern blotting to verify the success of the targeting event (Fig. 1c). Thus, probe A detected a $6.7-\mathrm{kb}$ EcoRI-KpnI fragment generated from the wild-type 11$\mathrm{kb}$ EcoRI-KpnI fragment after disruption of the PTHrP gene. Moreover, probe $B$, derived from sequences within the region of homology in the targeting vector, recognized a 1.0-kb fragment after PvulI digestion of the wildtype allele, as well as a $1.8-\mathrm{kb}$ Pvull fragment arising from the disrupted allele, but no other $P_{v u l I}$ fragments. The absence of additional random copies of replacement vector was verified by Southern blot analysis using neor as probe (data not shown).

\section{Generation of chimeric mice and germ line transmission}

Cells from three independent mutant clones $(6,43$, and 95) were introduced by microinjection into blastocysts of C57BL/6 mice to generate chimeric mice. Both clones 43 and 95 resulted in extensively chimeric male mice in the progeny, as determined by the presence of agouti coat color in the offspring. Five male chimeras (three from clone 43 and two from clone 95) gave germ-line transmission of the mutated PTHrP allele when mated to C57BL/ 6 females. Mice heterozygous for the targeted allele were identified by Southern blot analysis of tail genomic DNA. As expected, $50 \%$ of the agouti offspring carried the mutated PTHrP allele. These animals had no apparently distinct phenotype when compared with their wild-type littermates, grew normally, and were able to breed successfully. Chimeras from clones 43 and 95 were used to establish breeding colonies in the inbred 129 and outbred C57BL/ 6 backgrounds.

\section{Disruption of PTHrP gene results in perinatal recessive lethality}

To define the consequenses associated with complete absence of PTHrP, heterozygous mice were interbred and offspring were analyzed again by tail-tip DNA analysis 3 weeks after birth. From a total of 320 offspring analyzed, no homozygous PTHrP mutants were identified (Fig. 2a); this pattern suggested that absence of PTHrP was lethal. To characterize further the time point of lethality in homozygous mice, fetuses at day 18.5 of gestation were 


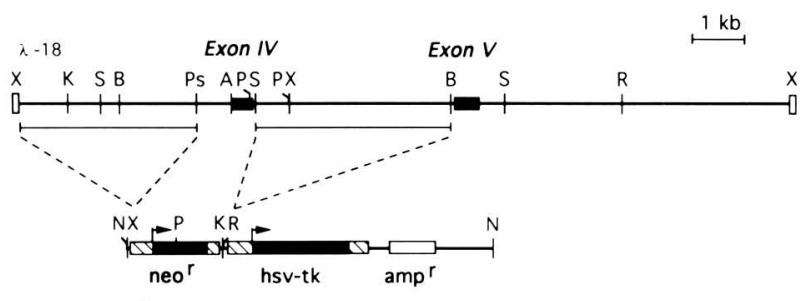

b

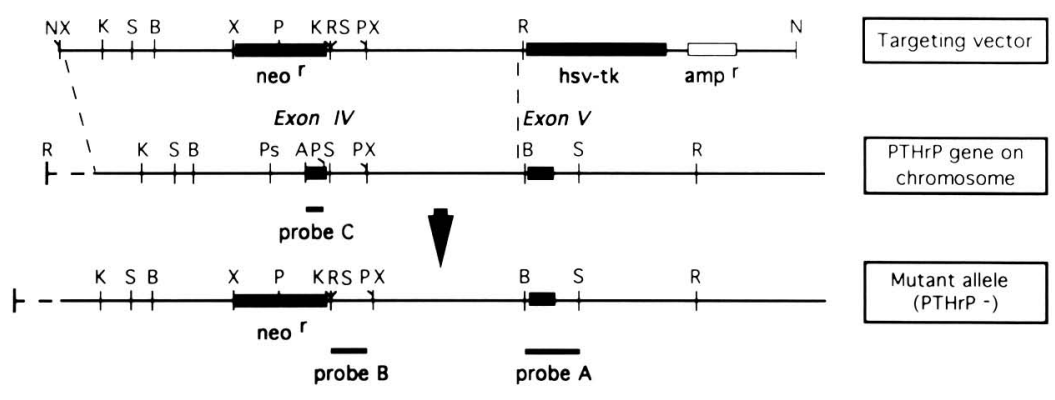

C

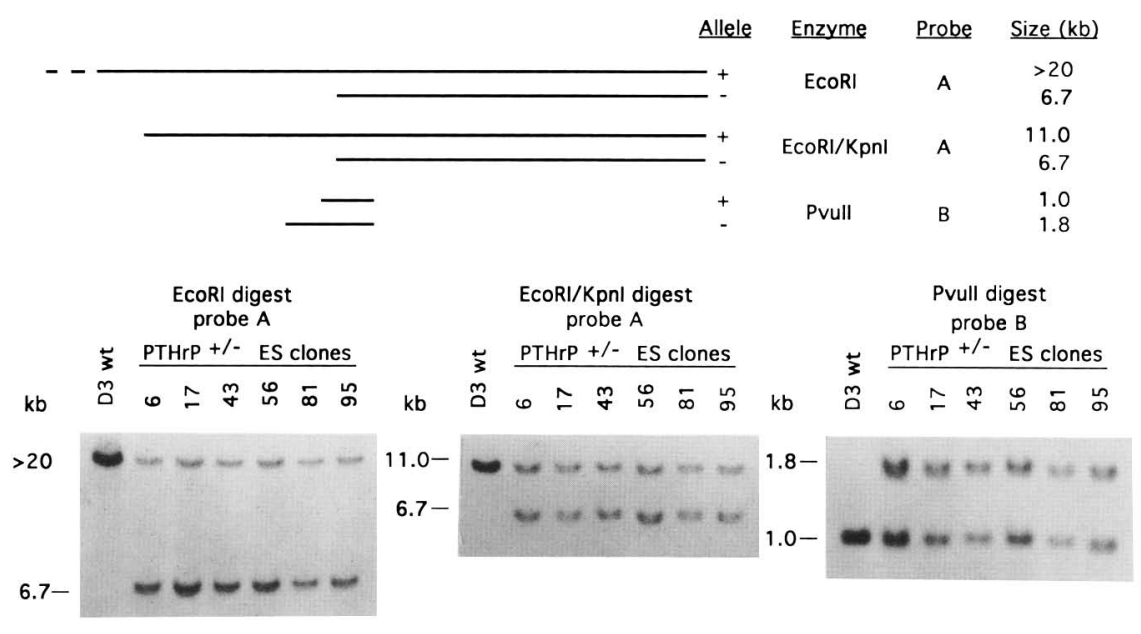

Figure 1. Disruption of the PTHrP gene in ES cells. $(a)$ Schematic representation of the murine PTHrP gene and pPNT-PTHrP targeting vector. (Top) Part of the mouse PTHrP gene contained in one phage insert; (solid boxes) exon IV, encoding part of the "prepro" region and amino acids $1-137$ of the mature protein, and exon $\mathrm{V}$, containing the last 2 amino acids of the protein as well as the $3^{\prime}$-untranslated region, including the polyadenylation signal. (Bottom) The pPNT vector linearized at the NotI (N) site. (Broken lines) Sites where the indicated PTHrP gene fragments were inserted. $\left(n e o^{r}\right)$ Bacterial neomycin resistance gene; (hsv-tk) herpes simplex virus thymidine kinase gene; $\left(\mathrm{amp}^{\mathrm{r}}\right)$ ampicillin resistance. (Hatched boxes) Phosphoglycerate kinase-1 gene (PGK-1) promoter (arrow $)$ and poly $(A)$ addition sequences. $(E)$ EcoRI; (S) SacI; (K) KpnI; (X) XhoI (X sites at the end of the phage sequence indicate phage-encoded sites); (Ps) PstI; (B) BamHI; (P) PvuII; (A) AvrII. For purposes of clarity, only pertinent restriction sites are depicted for some of the indicated restriction endonucleases. $(b)$ Homologous recombination event and targeted allele. (Top) The incoming targeting vector with PTHrP inserts designed to undergo homologous recombination with the PTHrP gene /shown in middle); (bottom) the ablated PTHrP gene after recombination. DNA probes are labeled. (Probe A) A 1.0-kb BamHI-SacI fragment not present in the targeting vector (contains exon $\mathrm{V}$ ), was used to screen for successful recombinant events; (probe B), a $0.65-\mathrm{kb}$ SacI-XhoI genomic DNA fragment, was in the targeting vector; (probe C) a 469-bp AvrII-PvuIl fragment containing most of exon IV, was used to confirm the absence of exon IV from the genome of PTHrP homozygous mutants (see Fig. 2c). (c) Southern blot analysis of ES clones targeted with the pPNT-PTHrP vector. Genomic DNA $(5 \mu \mathrm{g})$ prepared from nontransfected D3 ES cells (wt) and successfully targeted clones $(6,17,43,56,81,95)$ was digested with EcoRI, EcoRI-KpnI, or PvuII, Southern blotted, and probed with probes A or B, as shown. The sizes of genomic DNA fragments expected from the normal $|+|$ and disrupted $(-)$ alleles are indicated.

removed by cesarean section and genotyped by Southern blotting of tail genomic DNA (Fig. 2b). These analyses showed the presence of PTHrP homozygous mutant offspring, which appeared phenotypically distinct from wild-type and heterozygous littermates (see below). From witnessing spontaneous, full-term births as well as the behavior of animals delivered by cesarean section near term, it became evident that mice missing PTHrP died immediately after birth. These animals were hypotonic and made feeble attempts to breathe. Their skin color remained bluish-gray until they died within minutes of birth. Thus, PTHrP-negative homozygous mice survived until birth but died immediately after delivery, possibly from respiratory failure. Characteristically, these animals exhibited size and body weight similar to those of their wild-type and heterozygous littermates but had distinct phenotypic features characterized by domed skull, short snout and mandible, protruding tongue, and disproportionately short limbs (Fig. 3a). These features, distinguishable by gross examination of fetuses as early as day 16.5 of gestation, define a form of osteochondrodysplasia. An identical phenotype was obtained in progeny from each of the two independently derived clones of ES cells.

From 63 fetuses obtained by cesarean section at day $18.5,18$ were wild type $(28 \%)$, whereas 32 were heterozygous $(51 \%)$ and $13(21 \%)$ homozygous for the targeted PTHrP allele. This pattern, consistent with a Mendelian 
Figure 2. Genotype of 3-week-old pups and 18.5-day-old fetuses from heterozygous matings. Probe B was hybridized to $P v u I I-r e s t r i c t e d$ tail genomic DNA from 3-week-old pups $(a)$ and 18.5-day-old fetuses $(b)$, derived from crosses between heterozygous mice. An 1.8-kb fragment of equal intensity to the wild-type allele (1.0 kb) was detected in the heterozygous animals, whereas genomic DNA from homozygous fetuses contained only the mutant fragment. $(c)$ Tail genomic DNA from previously genotyped 18.5-day-old fetuses was restricted with BamHI, subjected to Southern blot analysis, and probed with a 469 -bp $A v r I I-P v u I I$ fragment containing most of exon IV (probe C; Fig. lb). The genotype of individual offspring is shown above the appropriate lane. $1+1+\mid$ Wild type $;(+1-1$, heterozygous; $1-1-1$ homozygous mutant.

pattern of inheritence, suggested that homozygous fetuses were not subject to prenatal lethality. To confirm that the homozygous mutant fetuses were devoid of mature PTHrP-coding sequences, tail genomic DNA from previously genotyped fetuses was restricted with BamHI, transferred to nitrocellulose filters, and hybridized with a 469-bp AvrII-PvuII fragment containing most of exon IV (probe $C_{;}$Fig. lb). In wild-type and heterozygous fetuses, this probe detected the expected 6.4$\mathrm{kb} \mathrm{BamHI}$ fragment (Figs. 1a and $2 \mathrm{c}$ ). However, the probe failed to hybridize to genomic DNA from homozygous fetuses; this result confirmed the deletion of exon IV of $\mathrm{PTHrP}$ from their genome. The recombinant allele is therefore not capable of directing the synthesis of a functional PTHrP protein.

\section{PTHrP homozygous mutants have abnormalities in endochondral bone development}

To further assess the phenotypic anomalies observed in the PTHrP homozygous mutants, whole 18.5-day postcoitum fetuses were stained with alizarin red $\mathrm{S}$ alone or in combination with alcian blue and cleared with potassium hydroxide to delineate the bony skeleton. A multitude of abnormalities became apparent in these preparations. Figure $3, \mathrm{~b}$ and $\mathrm{c}$, shows the lateral and caudal view of the skull, respectively, of a PTHrP homozygous mutant compared with that of a wild-type littermate. In addition to the foreshortening of the snout and mandible and the doming of the skull, the most striking feature in the homozygous mutant was the excessive degree of mineralization as delineated by staining with alizarin red S. In sharp contrast with the findings in the wild type littermates, the synchondroses of the bones forming the base of the mutant skull and the margins of the foramen magnum had undergone premature calcification/ossification and unification. Moreover, extensive staining with alizarin red $\mathrm{S}$ was noted on the tympanic bulla surrounding the inner ears and on the greater cornua of the hyoid bone, processes that normally begin to occur several days postpartum (Johnson 1933).

In contrast to the findings in endochondral /arising from cartilaginous mold) bone of the chondrocranium (cranial base and tympanic bullae), no abnormalities were noted in the cranial vault and in portions of the upper facial skeleton that develop by intramembranous ossification, without replacing a cartilaginous mold.

The advanced mineralization of the mutant cartilaginous skeleton was not restricted to the chondrocranium but was evident throughout the rest of the endochondral skeleton of the PTHrP-deficient mutants. Shown in Figure $3 \mathrm{~d}$ is the thoracic cage of a wild-type and PTHrPdeficient fetus. In the homozygous mutants there was a striking paucity of the normally unstained cartilaginous portions of the ribs and sternum. As a consequence, the ribs were short and splayed, and the sternum was also shorter than normal; these changes resulted in a narrow, bell-shaped thoracic cage with markedly diminished cross-sectional area (Fig. 3e).

Distinct calcification/ossification differences were also evident in the vertebral bodies. As shown in Figure $3 e$, the vertebral bodies were somewhat smaller in height than their normal counterparts and there was clearly advanced ossification involving both the vertebral bodies as well as the articular processes. Advanced ossification was also found in the pelvic bones (not shown).

The appendicular endochondral skeleton also revealed developmental abnormalities arising in the absence of PTHrP. Shown in Figure 3, $\mathrm{g}$ and $\mathrm{h}$, are cleared and stained anterior and posterior appendages, respectively, from normal and PTHrP homozygous mutant fetuses. In the homozygous mutant, the long bones were shorter and thicker than those from normal littermates, and had marked deformities. The bones had mildly splayed ends and irregular metaphyseal margins. Moreover, there was a striking diminution in the cartilaginous nonstaining portions of the bones as indicated by the diminished space between calcified/ossified segments.

\section{Microscopic analysis of mutant skeleton}

To define more precisely the cellular basis of the advanced skeletal calcification/ossification process noted in the PTHrP homozygous mutants, paraffin-embedded sections were prepared from various skeletal components of 18.5-day old fetuses. As an example, shown in Figure $4 \mathrm{a}$ are sections through the acetabulum from normal and mutant 18.5-day littermates. In the PTHrP homozygous mutant mouse the cartilage was virtually completely transformed into bone, whereas in the nor- 

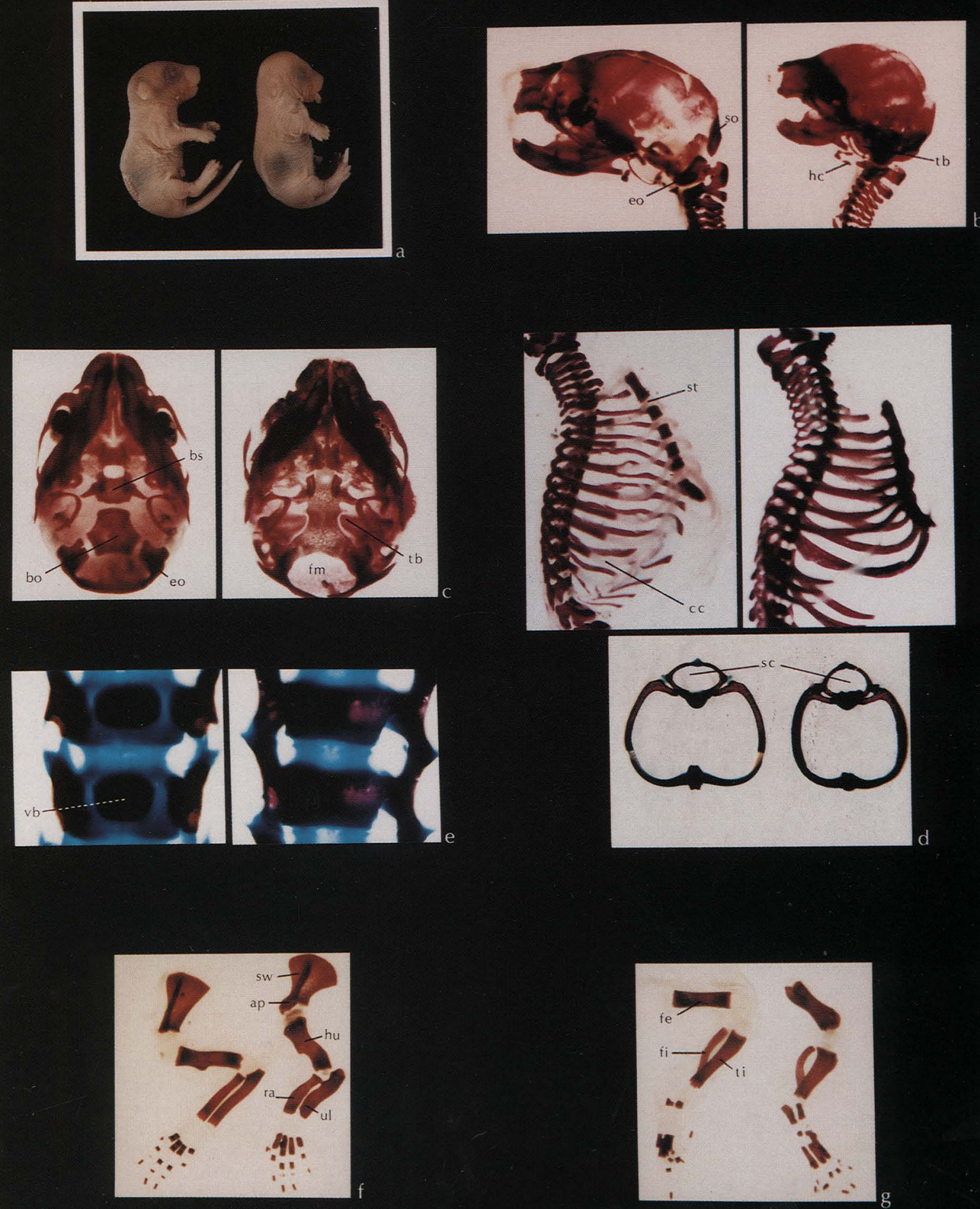

Figure 3. (See following page for legend.) 
Karaplis et al.
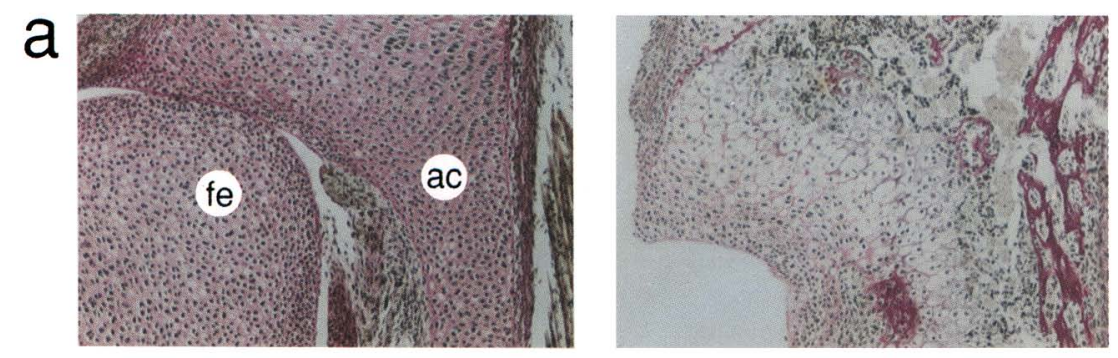

Figure 4. Microscopic findings in PTHrP homozygous mutants. $|a|$ Histological sections of the acetabulum (ac) from wild-type (left) and PTHrP-negative (right) 18.5-day fetuses. Note the advanced endochondral ossification process in the mutant. The head of the femur (fe) from the mutant specimen was lost during embedding. $(b, c)$ Ventral part of ribs from wild-type (left) and PTHrP homozygous mutant (right) littermates. Sections were obtained at the level of the fifth rib. In the normal specimen, hyaline cartilage chondrocytes (hc) are surrounded by perichondrium (pc), whereas the mutant cartilage is comprised of hypertrophic chondrocytes (hy), some clearly undergoing autolysis, surrounded by extensive perichondral bone $(\mathrm{pb})$ formation. These features are indicative of imminent ossification. $\{a, c \mid$ van Gieson's trichrome stain; $(b)$ stained with $\mathrm{H} \& \mathrm{E}$. Magnifications: $(a) 41 \mathrm{X}_{\text {; }}$ $(b, c) 103 X$.
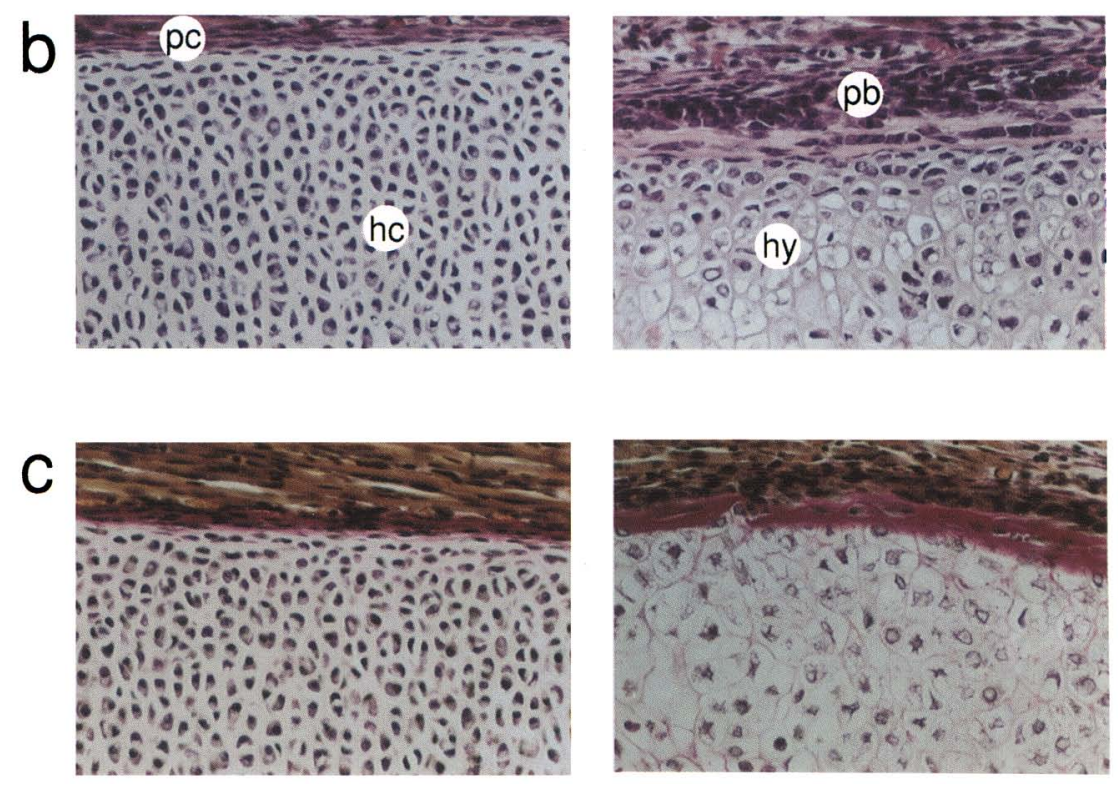

mal littermate it persisted as cartilage. These findings, also observed in other areas of abnormal alizarin red $S$ staining, were indicative of widespread premature maturation and ossification of the mutant cartilaginous skeleton as a consequence of the absence of PTHrP.
The ventral rib cage of the PTHrP homozygous mutants, which stained abnormally with alizarin red $S$, was also examined histologically. Shown in Figure 4 , b and c (left) is a longitudinal section through the ventral rib cage of a normal fetus at the level of the fifth rib. Here,

Figure 3. Macroscopic findings in PTHrP homozygous mutants. Fetuses from heterozygous matings were obtained by cesarean section at 18.5 days postcoitum and either fixed in buffered-formalin $(a)$ or stained with alizarin red $S(b-g)$ with $[d(b o t$ tom) and $e]$ or without alcian blue and cleared to reveal the skeleton. Specimens on the right of each panel represent the PTHrP homozygous mutants and those on the left the wild-type littermates. $(a)$ The mutant exhibits the chondrodysplastic phenotype characterized by a domed skull, short snout and mandible, protruding tongue, narrow thorax, and disproportionately short limbs. $(b)$ Lateral view of the skull showing the shortened and broadened mandible and doming of the mutant skull; note the abnormal staining of the cornua of the hyoid bone (hc) and the tympanic bulla (tb), as well as the untimely unification of the synchondrosis between the exoccipital (eo) and supraoccipital (so) bones. (c) Caudal view of the base of the skull; as in $b$, the mutant skull exhibits premature mineralization of the tympanic bullae and a paucity of cartilaginous synchondroses between the basoccipital (bo), exoccipital (eo), and basisphenoid (bs) bones. Note that there is no narrowing of the foramen magnum $(\mathrm{fm})$ where the spinal cord becomes continuous with the medulla oblongata. $[d, \mid$ top $)]$ thoracic cage; in the homozygote the sternum is shorter with no discernible cartilaginous sternebrae (st). The costal cartilage (cc) also demonstrates abnormal mineralization as indicated by alizarin staining. [d (bottom)] Transverse section of the thoracic cage at the level of the third rib. The mutant specimen shows the markedly diminished cross-sectional area of the thoracic cavity but there is no narrowing of the spinal canal (sc). (e) Lumbar spine; note the advanced mineralization of the mutant vertebral bodies $(\mathrm{vb})$ and associated articular processes. The vertebral bodies of the homozygote are somewhat smaller in height. $(f)$ Forelimbs; (g) hindlimbs; note the striking paucity of cartilaginous (nonstaining) components in the mutant specimens. In the homozygous the long bones are shorter and thicker; the humerus (hu), radius (ra), femur (fe), tibia (ti), and fibula (fi) are also deformed. The advanced mineralization process involving the appendicular skeleton is exemplified by the more extensive staining of the wing of the scapula (sw) and the acromion process (ap), and the small bones of the distal extremities, as well as by the presence of ossification centers in the epiphyses. 
the zone of the rib cartilage is composed of hyalin cartilage surrounded by fibrous perichondrium. In striking contrast, in the PTHrP homozygous mutants [Figure 4, b and $c$ (right)l, the rib cartilage was composed of more differentiated (hypertrophic) chondrocytes encased by perichondral bone, as indicated by the presence of characteristic bony matrix, active osteoblasts, and osteocytes. These changes, unlike those seen in the rest of the skeleton, however, do not represent an accelerated normal process; these changes never actually occur in the normal rib cage at this location. Normally, this hyaline rib cartilage calcifies only as part of a degenerative process. No chondrocyte maturation or perichondral bone formation occurs. The absence of PTHrP is thus associated not only with acceleration of the normal endochondral ossification process but also with abnormal maturation of hyaline rib chondrocytes with associated perichondral ossification. It is of interest to note, however, that hyaline cartilage of the trachea, larynx, and articular surfaces from PTHrP homozygous mutants was histologically normal (data not shown).

Because abnormal growth of long bones was an outstanding feature of the PTHrP homozygous mutant phenotype, studies also focused on the morphology of epiphyseal cartilages and growth plates. Light microscopic examination of the growth plates of long bones revealed marked abnormalities in the mutant fetuses as compared with their normal littermates (Fig. 5a,b). These abnormalities were mainly quantitative and consisted primarily of marked reduction in the height of the cartilaginous zones making up the growth plate. In particular, the zone of resting chondrocytes and the zones of proliferation and maturation were markedly shortened. The columns of proliferating chondrocytes were considerably shorter than normal and were arranged irregularly. The bony trabeculae of the primary spongiosa were shortened considerably and were somewhat distorted, that is, not strictly parallel. Their number was decreased; however,
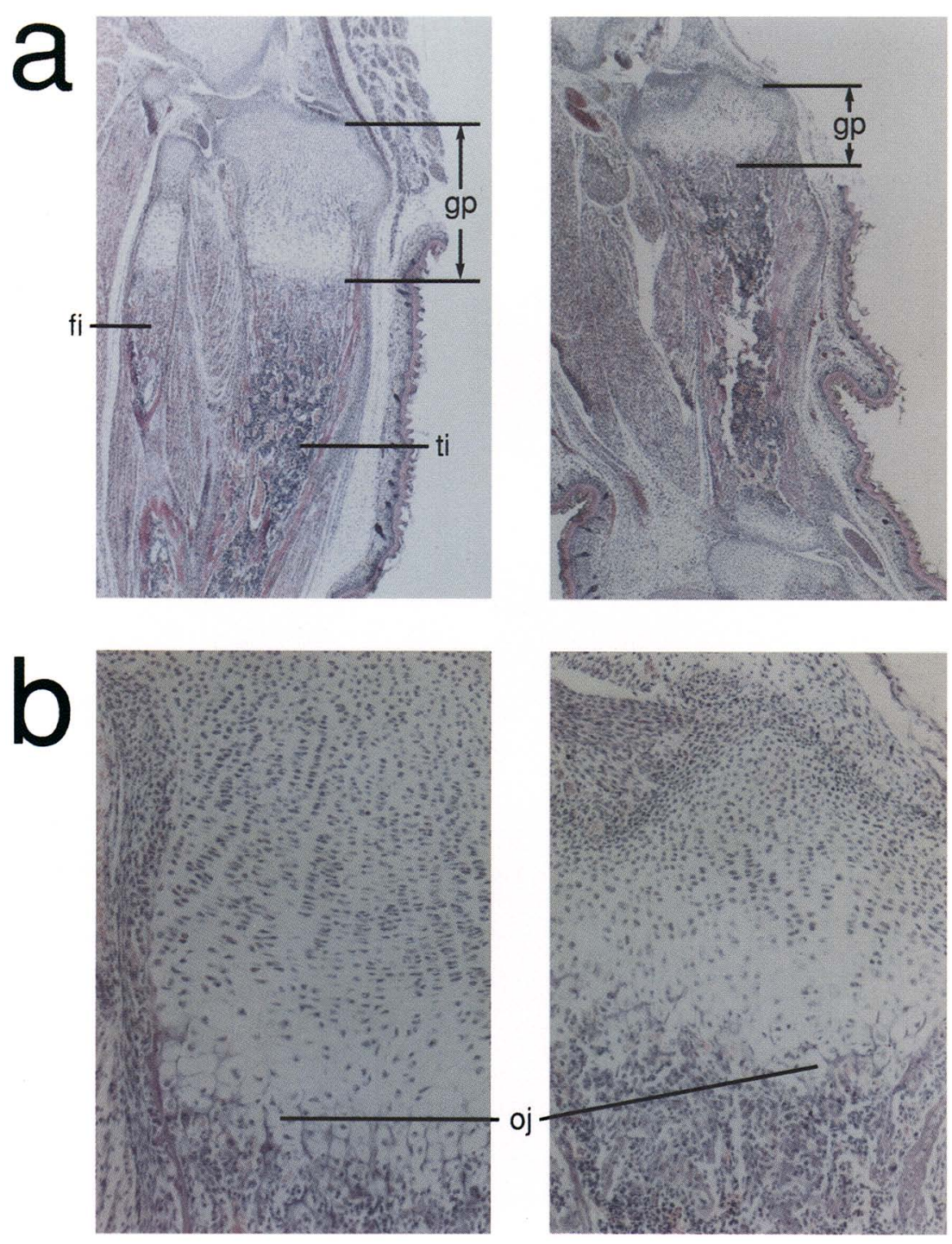

Figure 5. Proximal tibial growth plate abnormalities in 18.5-day PTHrP homozygous mutants. Light microscopy of growth plate cartilage of proximal tibia (ti) and fibula (fi) from wild-type (left) and PTHrP homozygous mutant $($ right $\mid$ littermates. $(a)$ Note the shortening and deformities of the long bones and the markedly diminished height of growth plate cartilage (gp) in the mutant animal. $(b)$ The normal and mutant proximal tibial growth plates at higher magnification. These representative views demonstrate the marked reduction in the columnar arrangement and number of proliferating chondrocytes, as well as the irregular osteochondral junction $\langle 0 j\rangle$ characteristic of the mutant growth plate. $\mathrm{H} \& \mathrm{E}$ staining. Magnifications: $(a) 10 \mathrm{X} ;(b)$ $41 \mathrm{X}$. 
the number and morphology of multinucleated chondroclasts and osteoclasts, as well the histological appearance of the periosteal ossification, were normal.

\section{Ontogeny of the skeletal abnormalities}

To define more precisely the ontogeny of the skeletal abnormalities associated with PTHrP deficiency, fetuses were examined at earlier times of gestation. Cleared specimens from fetuses 12.5 days postcoitum were stained with alizarin red $\mathrm{S}$ and alcian blue and examined for abnormalities. At this developmental stage, the mutant cartilaginous blastemata of long bones (Fig. 6a), as well as the rest of the cartilaginous skeleton (data not shown), were of apparently similar size and shape to those of their normal counterparts; thus, the process of mesenchymal condensation to form the initial cartilage appeared normal.

Whole skeletal preparations from fetuses at 14.5 days of gestation confirmed the nearly normal rate of skeletogenesis in the homozygous mutant animals at this stage of development (Fig. 6b). However, on careful examination, abnormalities were becoming apparent in rapidly growing bones, that is, the long bones of the forelimbs (Figure 6c) and hindlimbs (data not shown). As shown in Fig. 6c, the cartilage primordia of the ulna and radius from homozygous mutants were somewhat deformed and shorter when compared with those from normal littermates. Because the primary ossification centers in these cartilage primordia first appear by $\sim 14.5$ days postcoitum, the presence of these abnormalities suggests that the absence of PTHrP influences the development of the cartilaginous skeleton before the initiation of endochondral ossification.

\section{Gross and histological analysis of nonskeletal mutant tissues}

Because the PTHrP gene is expressed in many fetal tissues in a temporally and spatially specific pattern (Moniz et al. 1990; Campos et al. 1991; Senior et al. 1991; Stolpe et al. 1993), a thorough examination was undertaken to identify abnormalities in nonskeletal organs and tissues from PTHrP homozygous mutants. Gross examination of these animals was unremarkable except for the skeletal deformities already described. Moreover, histological assessment of multiple sections from a number of mutant tissues (listed in Materials and methods) failed to identify any other abnormalities.

\section{Discussion}

\section{Endochondral ossification and its disruption in PTHrP homozygous mutant mice}

Endochondral bone formation is a complex, multistep process requiring the sequential formation and degradation of cartilaginous structures that serve as templates for the developing bones (for reviews, see Recker 1992; Poole 1993). Early in development, genes such as Hoxa-1
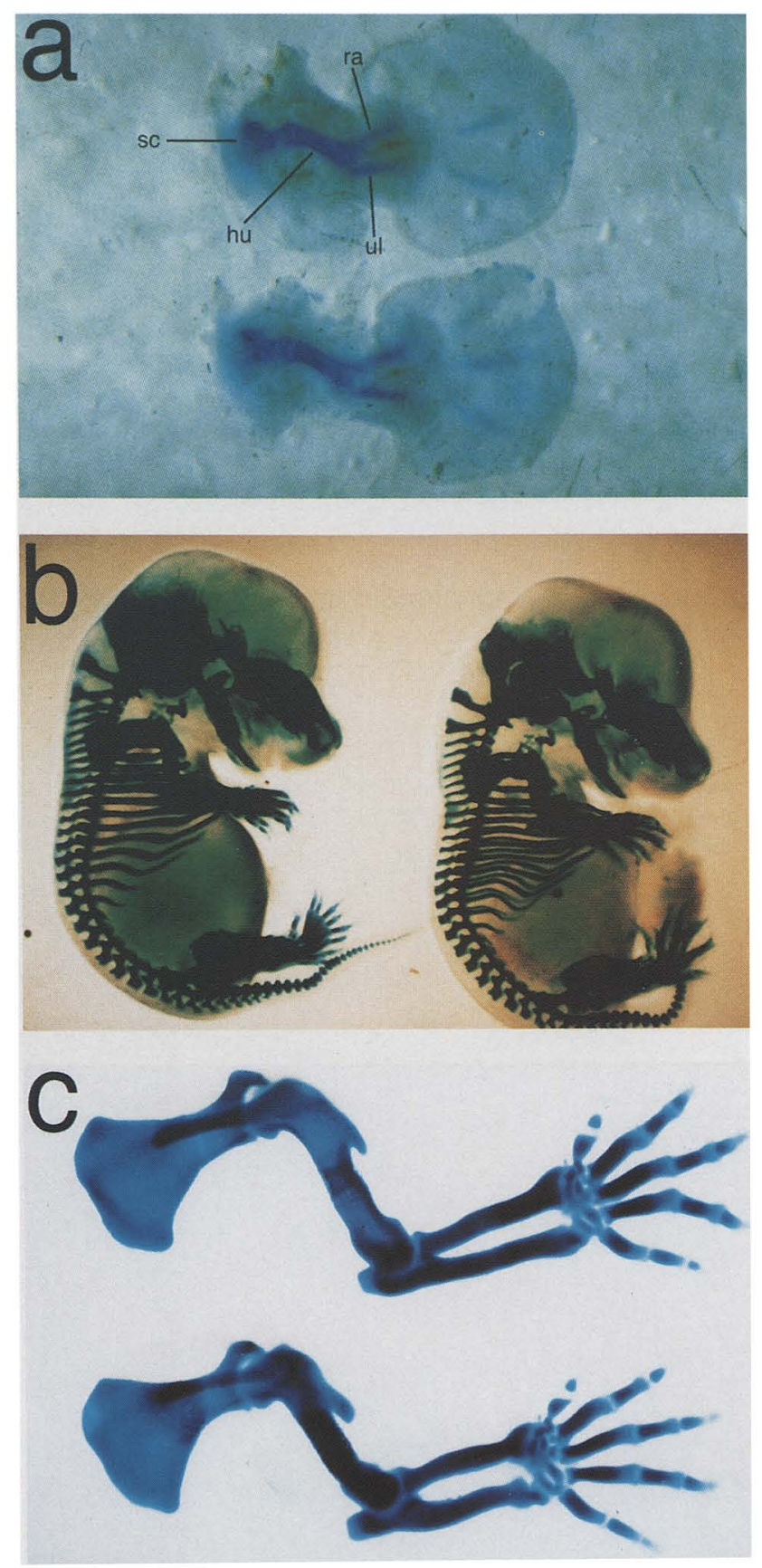

Figure 6. Ontogeny of long bone abnormalities. Alizarin red S-alcian blue-stained and cleared forelimbs of 12.5-day $(a)$ and 14.5-day $(c)$ wild-type $(t o p)$ and PTHrP homozygous mutant (bottom) littermates. In 12.5-day embryos, the scapula (sc), humerus (hu), radius (ra), and ulna ( $\mathrm{ul}$ ) are present as cartilaginous elements and the metacarpals are just chondrifying. At this stage there are no discernible differences between the wild-type and mutant animals. (b) At 14.5 days postcoitum, skeletal development continues at a nearly identical pace in both wildtype (left) and PTHrP homozygous mutants (right), but $(c)$ differences in the length of the long bones are becoming clearly evident at this stage, with the mutant ones being markedly shorter and deformed. 
(Lufkin et al. 1991) and Hoxc-8 (Le Mouellic et al. 1992) help to determine the identities of the specific bones appropriate for each unique region in the body plan. Bone morphogenic proteins (Lyons et al. 1990; Kingsley et al. 1992; Niswander and Martin 1993), fibroblast growth factor (Niswander and Martin 1993), and transforming growth factor $\beta$ (Newman 1988) are some of the factors that influence the initial differentiation of mesenchymal cells into chondrocytes. Although disruption of the PTHrP gene in mice has striking effects on the developing skeleton, PTHrP does not appear to influence this stage of differentiation (Fig. 6a); rather, it acts at a later stage on committed cells.

The current analysis of the PTHrP-deficient mouse provides a framework for hypotheses on the role of PTHrP in skeletal development. First, PTHrP appears to be needed for normal proliferation of chondrocytes. The absence of this effect is manifested as a marked reduction in the size of the growth plates of long bones. This effect would be expected, and was observed, to be most severe in rapidly growing bones, such as the long bones of the forelimbs and hindlimbs. Similarly, a proliferative abnormality may contribute to the diminished size of the early cartilaginous rudiments, as well. This proliferative abnormality observed in vivo may well correlate with in vitro findings that amino-terminal fragments of PTH promote proliferation of fetal growth plate chondrocytes (Koike et al. 1990; Burch and Lebovitz 1983). Second, in the absence of PTHrP, chondrocytes differentiate prematurely. This process results in a reduced number of proliferating chondrocytes, early hypertrophy and subsequent death of chondrocytes, and, associated premature bone formation. The effect of PTHrP on chondrocyte maturation in vivo may correlate with the effect of PTH in vitro to inhibit induction of alkaline phosphatase and matrix calcification in cultures of rabbit growth plate chondrocytes (Kato et al. 1990).

The mechanism whereby expression of the PTHrP gene regulates chondrocyte proliferation and differentiation remains to be determined. Local production and action of PTHrP may well mediate these activities. Both the PTHrP ligand (Moniz et al. 1990; Campos et al. 1991; Senior et al. 1991) and the receptors for amino-terminal PTH (and corresponding mRNAs) have been found in the growth plates of developing bone (Barling and Bibby 1985; Lee et al. 1992).

The accelerated endochondral ossification of the mutant skeleton is another striking aspect of the PTHrP. deficient phenotype. Precocious development of osteoblasts overlying the hypertrophic chondrocytes appears to be coupled to the acceleration of cartilage differentiation in the mutant mice. This leads to accelerated perichondrial bone development. In contrast, bones that are not formed over a cartilage mold, such as the parietal bones of the skull, do not develop prematurely in the mutant. It seems likely, therefore, that the premature bone formation over cartilage results from signals associated with accelerated differentiation of the chondrocytes. Such signals would provide a needed mechanism for the coordination between maturation of cartilage and the formation of bone on the cartilage surface. Thus, PTHrP could serve to modulate, directly or indirectly, the intricate interaction between the cartilaginous skeleton and the surrounding perichondrium during the process of endochondral ossification. Moreover, PTHrP appears to be involved in inhibiting promiscuous ossification from taking place, as exemplified by the striking anomalies observed at the hyaline rib cartilage of the PTHrP homozygous mutants. Again, this may reflect abnormal differentiation of chondrocytes to hypertrophic cells and the associated, equally abnormal, perichondral bone formation. Alternatively, it is possible that PTHrP modulates the maturation of chondrocytes and osteoblasts independently.

One can speculate that PTHrP may play a role in analogous situations, such as fracture healing, in which chondrocyte development precedes new bone formation, as well. In contrast, as the development of articular cartilage and intervertebral disk cartilage appears normal in the PTHrP-deficient mouse, chondrocytes in these regions may not respond to the same signals as chondrocytes within bone.

The cause of death in PTHrP-deficient mice in the early postnatal period is uncertain. It is tempting to surmise that the observed skeletal abnormalities lead to mechanical problems in respiration. Figure $3 \mathrm{~d}$ (bottom), depicting the markedly diminished cross sectional area of the thoracic cage in the homozygous mutant, is certainly compatible with this concept. In other forms of animal (Hepworth et al. 1990) and human (Spranger and Maroteaux 1991) skeletal dysplasias, decreased thoracic volume leads to pulmonary hypoplasia. Histologic examination of lungs from PTHrP homozygous mutant mice after natural birth did not reveal any developmental abnormalities. However, the lungs of these animals were not fully expanded. Furthermore, the lungs, removed at the time of delivery, did not float in saline; presumably, initial unsuccessful attempts to breathe may have led to anoxia and eventually to death. Alternatively, abnormalities of the base of the skull or vertebral column could lead to compression of crucial neurological structures. However, histological studies provided no evidence for this possibility. It is possible that PTHrP may act in the brain or elsewhere to mediate functions crucial for survival after birth.

\section{Skeletal dysplasias in mice and humans}

The mouse PTHrP gene has been localized to chromosome 6, region F-G (Seldin et al. 1992). A literature search for naturally occurring mutations mapping to this region has not disclosed any known natural mouse mutants phenotypically similar to the PTHrP-deficient strain. There are, however, several naturally occurring chondrodystrophic mouse mutants (for review, see Johnson 1986). Although all of these mutants have general features consistent with osteochondrodysplasia (domed skull, shortened long bones), the underlying genetic defects of these heterogeneous disorders for the most part have not been defined. 
Attempts to understand the factors that may influence cartilage growth and development using transgenic technology have focused primarily on overexpressing mutated forms of type II collagen (Garofalo et al. 1991; Vandenberg et al. 1991, Metsäranta et al. 1992). As expected, these mutations disturbed the assembly and processing of the homotrimeric type II collagen molecule in cartilage, resulting in chondrodysplasia. However, the phenotype associated with absence of PTHrP is distinct from all other forms, both natural and transgenic. In no case has accelerated bone formation been observed as an integral feature of the phenotype, and abnormalities in cartilage differentiation have never been described.

The present study raises the question of whether a direct comparison can be made between the phenotype of the PTHrP-deficient mouse and known human skeletal dysplasias. As with animal models, little is known about the etiology and pathogenesis of most forms of human osteochondrodysplasias (International Working Group on Constitutional Diseases of Bone, 1992). Of those disorders with characterized patterns of inheritence, none has been mapped to chromosome region 12p12.1-p11.2, where the human PTHrP gene has been localized (Mangin et al. 1988). The histological characteristics of long bone growth plate cartilage from PTHrP homozygous mutant mice, however, do bear resemblance to those from patients with achondroplasia, the most common form of human skeletal dysplasia (Jaffe 1972; Briner et al. 1991). However, the genetic heterogeneity within and between this human disorder and its possible relationship to the phenotype of PTHrP-deficient mice remains to be clarified.

Another form of human skeletal dysplasia that may bear relevance to the present findings is Albright's hereditary osteodystrophy (AHO). Patients with this disorder exhibit a constellation of somatic abnormalities, including foreshortened long bones and domed skull (Albright et al. 1942) somewhat similar to those seen in the PTHrP-less mouse. AHO is an autosomal dominant disorder in which one copy of the of the $\alpha$ subunit of stimulatory $G$ protein $\left.\mid G_{s} \alpha\right)$ gene is defective (Levine et al. 1988). Because the PTH-PTHrP receptor signals, at least partly, through activation of $\mathrm{G}_{\mathrm{s}} \alpha$ (Abou-Samra et al. 1992), it is conceivable that the skeletal defects associated with AHO may reflect insufficient propagation of signals elicited by skeletal PTHrP. Unfortunately, histological evaluation of the growth plates in this disorder has not been performed, so that possible resemblance of AHO and the PTHrP homozygous mutant phenotype is difficult to evaluate.

\section{The effect of PTHrP deletion on other developing tissues}

It is rather puzzling that deletion of the PTHrP gene affects primarily the developing skeleton, as $\mathrm{PTHr}$ P expression has been shown in many fetal tissues (Moniz et al. 1990; Campos et al. 1991; Senior et al. 1991; Stolpe et al. 1993). The effects of PTHrP may be important, but may not lead to striking morphologic changes in most organs. Alternatively, other factors, either local or humoral, may compensate for the absence of PTHrP. A likely candidate that may function as a PTHrP-like factor is PTH. Circulating PTH may itself serve as ligand for the PTH-PTHrP receptor and thereby mitigate the effects of PTHrP deficiency. Why might cartilage be exempted from this effect of PTH lor other PTHrP-like factors|? Several explanations are plausible. Cartilage has a rather high synthetic and proliferative rate but a poor supply of nutrients, obtained primarily by diffusion. Such an anatomic arrangement may limit the ability of humoral factors from reaching their sites of action. Alternatively, circulating levels of PTH may not be sufficient to mimic critical, particularly high, local concentrations of PTHrP. Furthermore, the effects of PTHrP on bone may be mediated by receptors that do not recognize PTH.

Fetal PTH cannot, however, be the sole factor mitigating the loss of PTHrP. PTHrP is synthesized in the preimplantation mouse embryo, long before fetal PTH is synthesized. In the blastocyst, PTHrP is found in the first endoderm derivatives of the inner cell mass and, subsequently, in the trophectoderm cells; this early synthesis of PTHrP suggests a paracrine or autocrine role for the PTH-PTHrP receptor signaling system in parietal endoderm differentiation (Stolpe et al. 1993). At this early stage, it is possible that maternal PTHrP or PTH may be able to complement a fetal PTHrP deficiency. Alternatively, completely separate signaling systems may be able to substitute for PTHrP, as functional redundancy appears to represent a general phenomenon in complex developmental processes.

\section{Materials and methods}

Generation of a PTHrP probe and cloning of the murine PTHrP gene

The primers used to amplify exon III of the rat PTHrP gene were derived from genomic exonic sequences (Karaplis et al. 1990). The sense oligonucleotide was PLP-1 $15^{\prime}$-CGC GCG GTG TCT GAG CAC CAG CTA CT-3'), and the antisense oligonucleotide was PLP-2 (5'-GCT GGG CTC CAG GGA GGT CGA GGT CG-3'). Amplification was carried out in a final volume of 100 $\mu l$ in $1 \times$ PCR buffer [10 mM Tris- $\mathrm{HCl}(\mathrm{pH} 8.3), 50 \mathrm{mM} \mathrm{KCl}, 1.5$ $\mathrm{mM} \mathrm{MgCl}, 0.01 \%$ gelatin], $200 \mu \mathrm{M}$ dNTPs, $1 \mu \mathrm{M}$ of each primer, $2 \mu \mathrm{g}$ of rat genomic DNA as template, and $25 \mathrm{U} / \mathrm{ml}$ of Taq polymerase (Cetus) under a layer of paraffin oil. PCR cycling was for $4 \mathrm{~min}$ at $92^{\circ} \mathrm{C}, 2 \mathrm{~min}$ at $65^{\circ} \mathrm{C}$, and $2 \mathrm{~min}$ at $72^{\circ} \mathrm{C}$ for 30 cycles. The amplified 414-bp product was subcloned in pGEM-7 (Promega) and used as a probe to screen an EMBL3 BALB/c mouse genomic library /Clontech Laboratories Inc., Palo Alto, CA). Individual clones were plaque-purified, and XhoI-restricted fragments were subcloned into Sall sites in pGEM-2 (Promega) for restriction mapping and sequencing. Nucleotide sequences were determined by the dideoxy chain termination method (Sanger et al. 1977). Clone $\lambda-18$ used for the construction of the targeting vector contained $\sim 15 \mathrm{~kb}$ of mouse genomic DNA, including exons IV and V of the murine PTHrP gene (see Fig. 1) (Mangin et al. 1990).

\section{Construction of a PTHrP targeting vector}

A 5.2 -kb Xhol genomic fragment containing exon IV of the 
PTHrP gene was isolated from $\lambda-18$ and subcloned into the SalI site of pGEM-2. The plasmid was digested, and a 3.5-kb PstI fragment consisting of sequences 5 ' to exon IV was purified. The ends of this fragment were made blunt with Klenow polymerase and ligated to a similarly treated $X h O I$ site in the pPNT plasmid (Tybulewicz et al. 1991). Both Xhol sites were regenerated with this procedure in the resultant plasmid, pPNT/PstI.

Phage $\lambda-18$ DNA was digested to yield a $4.6-\mathrm{kb}$ SacI fragment containing sequences $3^{\prime}$ to exon IV and exon V of the PTHrP gene. This fragment was subcloned into the SacI polylinker site of pGEM-2 and the resulting plasmid was digested with BamHI. The 1.0-kb BamHI fragment containing exon $\mathrm{V}$ was removed to be used as a probe (probe A), whereas the BamHI sites in the plasmid were modified by the addition of EcoRI linkers and religated. Restriction digestion of this plasmid produced a 3.6$\mathrm{kb} E c o \mathrm{RI}$ fragment that was subcloned into the EcoRI polylinker site of pPNT/PstI. In this construct the transcriptional orientation for the neo ${ }^{x}$ gene was the same as for the PTHrP gene. The resulting plasmid, designated as pPNT-PTHrP, was linearized at the unique NotI site in the pPNT backbone before electroporation.

\section{Tissue culture, transfection, and selection}

D3 ES cells were grown on gelatin-coated dishes on a feeder layer of mitotically inactivated $/ \gamma$-irradiated with 1500 rads for $30 \mathrm{~min}$ ) primary embryonic fibroblasts. The feeder cells were prepared essentially as described (Robertson 1987) from 13.5day-old embryos derived from matings of $B A L B / c$ female mice with males homozygous for replacement of the $\beta_{2}$-microglobulin gene with the bacterial neor gene (Zijlstra et al. 1989). This permitted the feeders to survive G418 selection. D3 cells were grown in complete ES medium [Dulbecco's modified Eagle medium containing $15 \%$ fetal calf serum, nonessential amino acids, $0.1 \mathrm{mM} \beta$-mercaptoethanol, penicillin/streptomycin and $1000 \mathrm{U} / \mathrm{ml}$ of leukemia inhibitory factor] at $37^{\circ} \mathrm{C}$ and $5 \% \mathrm{CO}_{2}$.

For electroporation, $8 \times 10^{6}$ exponentially growing ES cells were trypsinized, resuspended in $0.8 \mathrm{ml} \mathrm{HBS}[137 \mathrm{mM} \mathrm{NaCl}, 5$ $\mathrm{mM} \mathrm{KCl}, 0.7 \mathrm{mM} \mathrm{Na}_{2} \mathrm{HPO}_{4}, 6 \mathrm{~mm}$ glucose, $20 \mathrm{~mm}$ HEPES $\mid \mathrm{pH}$ 7.1)] containing $0.1 \mathrm{mM} \beta$-mercaptoethanol and $30 \mu \mathrm{g}$ of linearized pPNT-PTHrP targeting vector, and electroporated with a Bio-Rad Gene Pulser at $400 \mathrm{~V}, 25 \mu \mathrm{F}$ at room temperature. The cells were then added to nonselective medium and plated on feeder cells on $90-\mathrm{mm}$ dishes for $36 \mathrm{hr}$. After this recovery period, selection was started with G418 $(300 \mu \mathrm{g} / \mathrm{ml})$ for 9 days and FIAU $(0.2 \mu \mathrm{M})$ for only the first 5 days of selection. Doubly resistant ES clones were isolated and transferred in 24-well plates with embryonic fibroblast feeder layer cells and expanded to $70 \%$ confluency in the presence of $300 \mu \mathrm{g} / \mathrm{ml}$ of $\mathrm{G} 418$. The cells from each well were trypsinized, and one-half was frozen, whereas the rest were expanded in the absence of a feeder layer for DNA preparation.

\section{Identification of homologous recombinant clones}

Cells were lysed at $37^{\circ} \mathrm{C}$ in $400 \mu \mathrm{l}$ of lysis buffer $(10 \mathrm{~mm}$ Tris$\mathrm{HCl}, 1 \mathrm{mM}$ EDTA, $0.1 \mathrm{M} \mathrm{NaCl}, 1 \% \mathrm{SDS}$, and $0.5 \mathrm{mg} / \mathrm{ml}$ of proteinase $\mathrm{K}$ ) for $16 \mathrm{hr}$. After phenol extraction and ethanol precipitation, $\sim 5 \mu \mathrm{g}$ of genomic DNA was subjected to restriction enzyme digestion with $E c 0$ RI, fractionated on an $0.7 \%$ agarose gel, and transferred to nitrocellulose membranes. Hybridization with the 1.0-kb BamHI-SacI fragment (probe A) (Fig. la) was carried out according to standard procedures (Sambrook et al. 1989). ES clones identified as positive were thawed and reexpanded once without drug selection. Exponentially growing ES cells were trypsinized and divided in aliquots. One was used for further analysis by genomic Southern blotting, whereas the rest were frozen and used subsequently for blastocyst injections.

\section{Generation of chimeric mice}

Aliquots of successfully targeted ES clones were plated on embryonic fibroblast feeder layers in complete ES medium and allowed to reach $60-70 \%$ confluence before injection. Chimeras were generated as described by Bradley (1987). Briefly 12-17 ES cells were injected into the blastocoele cavity of 3.5-day-old blastocysts that were flushed from the uterine horns of naturally mated $\mathrm{C} 57 \mathrm{Bl} / 6$ females. Injected blastocysts were allowed to recover in DMEM containing $10 \%$ FCS for $1-2 \mathrm{hr}$ at $37^{\circ} \mathrm{C}$ before transfer to uteri of 2.5-day postcoitum, pseudopregnant $B 6 D 2 F_{1}$ recipients. Pups were born after 17 days and were scored with respect to chimerism, as judged visually by the presence of agouti pigmentation in the coat 10 days later.

\section{Preparation of genomic DNA}

Pieces of tail or yolk sac were placed in $500 \mu$ l of TNE buffer [Tris- $\mathrm{HCl}$ (pH 8.5), $5 \mathrm{~mm}$ EDTA, 0.2\% SDS, $200 \mathrm{~mm} \mathrm{NaCl}$ ] containing $100 \mu \mathrm{g} / \mathrm{ml}$ of proteinase $\mathrm{K}$ and incubated with agitation at $55^{\circ} \mathrm{C}$ for $8-16 \mathrm{hr}$. Genomic DNA was precipitated once with isopropanol, resuspended in water, phenol-choroform extracted, and ethanol precipitated. Generally, the DNA was resuspended in $100 \mu \mathrm{l}$ of TE buffer and $10 \mu \mathrm{l}(\sim 5 \mu \mathrm{g})$ were used subsequently for Southern blot analysis.

\section{Histology and tissue preparation}

Fresh tissue samples were obtained from fetuses derived from heterozygous matings and delivered at day 18.5 of gestation. For histology, fetuses were fixed in buffered $10 \%$ formalin. After fixation, tissues and internal organs /calvarium, brain, pituitary, skin, trachea, lung, esophagus, stomach, small and large intestine, liver, speen, pancreas, kidney, urinary bladder, heart, blood vessels, adrenals, thyroid, parathyroid, thymus) were embedded in paraffin, sectioned $(5-10 \mu \mathrm{m}$ thick), and stained with hematoxylin-eosin (H\&E). Carcasses were decalcified in neutral $40 \%$ EDTA, and samples from different parts of the skeleton were embedded in paraffin. Sections 5-10 $\mu \mathrm{m}$ thick were cut from several levels of the block. Sections of skeletal samples were stained with $H \& E$, and selected samples were stained with van Gieson's trichrome stain.

For staining and visualization of whole skeletons, fetuses were dissected and stained with alizarin red S or alcian blue, or both, as described previously (McLeod 1980).

\section{Acknowledgments}

We are grateful to Tyler Jacks for providing us with D3 ES cells and Jesse Dausman for her help and encouragement. The excellent technical assistance of Elenore Samson with the histology is also gratefully acknowledged. We also thank Toru Motokura, En Li, Glenn Dranoff, Simon Thompson, and Peter Carmeliet for helpful discussions, and Baker Al Akad and François FockTave Hiou-Tim for technical assistance. This work was supported in part by National Institutes of Health grants DK1 1794 and HL37569; A.C.K. was supported by a Medical Research Council of Canada Centennial Fellowship Award, which is gratefully acknowledged.

The publication costs of this article were defrayed in part by payment of page charges. This article must therefore be hereby 
marked "advertisement" in accordance with 18 USC section 1734 solely to indicate this fact.

\section{References}

Abou-Samra, A.-B., H. Jüppner, T. Force, M.W. Freeman, X.-F. Kong, E. Schipani, P. Urena, J. Richards, J.V. Bonventre, J.T. Potts Jr., H.M. Kronenberg, and G.V. Segre. 1992. Expression cloning of a common receptor for parathyroid hormone and parathyroid hormone-related peptide from rat osteoblastlike cells: A single receptor stimulates intracellular accumulation of both CAMP and inositol trisphosphates and increases intracellular free calcium. Proc. Natl. Acad. Sci. 89: 2732-2736.

Albright, F., C.H. Burnett, P.H. Smith, and W. Parson. 1942. Pseudohypoparathyroidism-an example of the "SeabrightBantam syndrome". Endocrinology 30: 922-932.

Barling, P.M. and N.J. Bibby. 1985. Study of the localization of $\left[{ }^{3} \mathrm{H}\right]$ bovine parathyroid hormone in bone by light microscope autoradiography. Calcif. Tissue Int. 37: 441-446.

Bradley, A. 1987. Production and analysis of chimeric mice. In Teratocarcinomas and embryonic stem cells: A practical approach (ed. E.J. Robertson), pp. 113-152. IRL Press, Washington, D.C.

Briner, J., A. Giedion, and M.A. Spycher. 1991. Variation of quantitative and qualitative changes of endochondral ossification in heterozygous achondroplasia. Pathol. Res. Pract. 187: 271-278.

Burch, W.M. and H.E. Lebovitz. 1983. Parathyroid hormone stimulates growth of embryonic chick pelvic cartilage in vitro. Calcif. Tissue Int. 35: 526-532.

Campos, R.V., S.L. Asa, and D.J. Drucker. 1991. Immunocytochemical localization of parathyroid hormone-like peptide in the rat fetus. Cancer Res. 51: 6351-6357.

Capecchi, M.R. 1989. Altering the genome by homologous recombination. Science 244: 1288-1292.

Doetschman, T.C., H. Eistetter, M. Katz, W. Schmidt, and R. Kemler. 1985. The in vitro development of blastocyst-derived embryonic stem cell lines: Formation of visceral yolk sac, blood islands and myocardium. 1. Embryol. Exp. Morphol. 87: 27-45.

Garofalo, S., E. Vuorio, M. Metsaranta, R. Rosati, D. Toman, J. Vaughan, G. Lozano, R. Mayne, J. Ellard, W. Horton, and B. de Crombrugghe. 1991. Reduced amounts of cartilage collagen fibrils and growth plate anomalies in transgenic mice harboring a glycine-to-cysteine mutation in the mouse type II procollagen $\alpha_{1}$-chain gene. Proc. Natl. Acad. Sci. 88: 96489652.

Hepworth, W.B., R.E. Seegmiller, and I.C. Carey. 1990. Thoracic volume reduction as a mechanism for pulmonary hypoplasia in chondrodystrophic mice. Pediatr. Pathol. 10: 919-929.

International Working Group on Constitutional Diseases of Bone. 1992. International classification of osteochondrodysplasias. Am. J. Med. Genet. 44: 223-229.

Jaffe, H.L. 1972. Achondroplasia. In Metabolic, degenerative, and inflammatory diseases of bones and joints (ed. H.L. Jaffel, pp. 193-206. Urban and Schwarzenberg, MünchenBerlin-Wien, Germany.

Johnson, D.R. 1986. The cartilaginous skeleton. In The genetics of the skeleton (ed. D.R. Johnson), pp. 40-117. Oxford University Press, New York.

Johnson, M.L. 1933. The time and order of appearance of ossification centers in the albino mouse. Am. J. Anat. 52: 241271.

Jüppner, H., A.-B. Abou-Samra, S. Uneno, W.X. Gu, J.T. Potts Jr., and G.V. Segre. 1988. The parathyroid hormone-like peptide associated with humoral hypercalcemia of malignancy and parathyroid hormone bind to the same receptor on the plasma membrane of ROS $17 / 2.8$ cells. I. Biol. Chem. 263: 8557-8560.

Jüppner, H., A.-B. Abou-Samra, M. Freeman, X.-F. Kong, E. Schipani, J. Richards, L.F. Kolakowski Jr., J. Hock, J.T. Potts Ir., H.M. Kronenberg, and G.V. Segre. 1991. A G proteinlinked receptor for parathyroid hormone and parathyroid hormone-related peptide. Science 254: 1024-1026.

Karaplis, A.C., T. Yasuda, G.N. Hendy, D. Goltzman, and D. Banville. 1990. Gene encoding parathyroid hormone-like peptide: Nucleotide sequence of the rat gene and comparison with the human homologue. Mol. Endocrinol. 4: 441-446.

Kato, Y., A. Shimazu, K. Nakashima, F. Suzuki, A. Jikko, and M. Iwamoto. 1990. Effects of parathyroid hormone and calcitonin on alkaline phosphatase activity and matrix calcification in rabbit growth-plate chondrocyte cultures. Endocrinology 127: 114-118.

Kingsley, D.M., A.E. Bland, J.M. Grugger, P.C. Marker, L.B. Russell, N.G. Copeland, and N.A. Jenkins. 1992. The mouse short ear skeletal morphogenesis locus is associated with defects in a bone morphogenetic member of the TGF $\beta$ superfamily. Cell 71: 399-410.

Koike, T., M. Iwamoto, A. Shimazu, K. Nakashima, F. Suzuki, and Y. Kato. 1990. Potent mitogenic effects of parathyroid hormone (PTH) on embryonic chick and rabbit chondrocytes. I. Clin. Invest. 85: 626-631.

Le Mouellic, H., Y. Lallemand, and P. Brulet. 1992. Homeosis in the mouse induced by a null mutation in the Hox-3.1 gene. Cell 69: 251-264.

Lee, K., A. Bond, H. Saito, S. Chiba, and G.V. Segre. 1992. Visualization of PTH action in intact bone: Differential induction of the protooncogene c-fos by PTH. I. Bone Miner. Res. (Suppl. 1) 7: S-107.

Levine, M.A., T.G. Ahn, S.F. Klupt, K.D. Kaufman, P.M. Smallwood, H.R. Bourne, K.A. Sullivan, and C. Dop. 1988. Genetic deficiency of the $\alpha$ subunit of guanine nucleotide-binding protein $\mathrm{G}_{\mathrm{s}}$ as the molecular basis for Albright hereditary osteodystrophy. Proc. Natl. Acad. Sci. 85: 617-621.

Lufkin, T., A. Dierich, M. LeMeur, M. Mark, and P. Chambon. 1991. Disruption of the Hox-1.6 homeobox gene results in defects in a region corresponding to its rostral domain of expression. Cell 66: 1105 1119.

Lyons, K.M., R.W. Pelton, and B.L. Hogan. 1990. Organogenesis and pattern formation in the mouse: RNA distribution patterns suggest a role for bone morphogenic protein-2A (BMP2A). Development 109: 833-844.

Mangin, M., A.C. Webb, B.E. Dreyer, J.T. Posillico, K. Ikeda, E.C. Weir, A.F. Stewart, N.H. Bander, L. Milstone, D.E. Barton, U. Francke, and A.E. Broadus. 1988. Identification of a cDNA encoding a parathyroid hormone-like peptide from a human tumor associated with humoral hypercalcemia of malignancy. Proc. Natl. Acad. Sci. 85: 597-601.

Mangin, M., K. Ikeda, and A.E. Broadus.1990. Structure of the mouse gene encoding parathyroid hormone-related peptide. Gene 95: 195-202.

Martin, T.J., J.M. Moseley, and M.T. Gillespie. 1991. Parathyroid hormone-like protein: Biochemistry and molecular biology. Crit. Rev. Biochem. Mol. Biol. 26: 377-395.

Metsäranta, M., S. Garofalo, G. Decker, M. Rintala, B. de Crombrugghe, and E. Vuorio. 1992. Chondrodysplasia in transgenic mice harboring a 15-amino acid deletion in the triple helical domain of proal(II) collagen chain. J. Cell Biol. 118: 203-212.

McLeod, M.J. 1980. Differential staining of cartilage and bone in 
whole mouse fetuses by alcian blue and alizarin red S. Teratology 22: 299-301.

Moniz, C., P.B.J. Burton, A.N. Malik, M. Dixit, J.P. Banga, K. Nicolaides, P. Quirke, D.E. Knight, and A.M. McGregor. 1990. Parathyroid hormone-related peptide in normal human fetal development. I. Mol. Endocrinol. 5: 259-266.

Newman, S.A. 1988. Lineage and pattern in the developing vertebrate limb. Trends Genet. 4: 329-332.

Niswander, L. and G.R. Martin. 1993. FGF-4 and BMP-2 have opposite effects on limb growth. Nature 361: 68-71.

Poole, A.R. 1993. Cartilage in health and disease. In Arthritis and allied conditions: A textbook of rheumatology led. D.J. McCarty and W.J. Koopman), pp. 279-333. Lea and Febiger, Philadelphia, PA.

Recker, R.R. 1992. Embryology, anatomy, and microstructure of bone. In Disorders of bone and mineral metabolism led. F.L. Coe and M.J. Favus), pp. 219-240. Raven Press, New York.

Robertson, E.J. 1987. Embryo-derived stem cell lines. In Teratocarcinomas and embryonic stem cells: A practical approach (ed. E.J. Robertson), pp. 71-112. IRL Press, Washington, D.C.

Sambrook, J., E.F. Fritsch, and T. Maniatis. 1989. Analysis of genomic DNA by Southern hybridization. In Molecular cloning: A laboratory manual, 2nd ed. pp. 9.31-9.58. Cold Spring Harbor Laboratory Press, Cold Spring Harbor, New York.

Sanger, F., S. Nicklen, and A.R. Coulson. 1977. DNA sequencing with chain-terminating inhibitors. Proc. Natl. Acad. Sci. 74: 5463-5467.

Seldin M.F., M.-G. Mattei, and G.N. Hendy. 1992. Localization of mouse parathyroid hormone-like peptide gene (Pthlh) to distal chromosome 6 using interspecific backcross mice and in situ hybridization. Cytogenet. Cell Genet. 60: 252-254.

Senior, P.V., D.A. Heath, and F. Beck. 1991. Expression of parathyroid hormone-related protein mRNA in the rat before birth: Demonstration by hybridization histochemistry. $\%$ Mol. Endocrinol. 6: 281-290.

Spranger, J. and P. Maroteaux. 1991. The lethal osteochondrodysplasias. Adv. Hum. Genet. 19: 1-103.

Stewart, A.F., W.J. Burtis, M. Mangin, K. Ikeda, K.L. Insogna, and A.E. Broadus. 1989. Purification and molecular cloning of a novel parathyroid hormone-like protein responsible for humoral hypercalcemia of malignancy. Cancer Cells 7: 339342.

Stolpe, A. van de, M. Karperien, C.W.G.M. Löwik, H. Jüppner, G.V. Segre, A.-B. Abou-Samra, S.W. de Laat, and L.H.K. Defize. 1993. Parathyroid hormone-related peptide as an endogenous inducer of parietal endoderm differentiation. 1 . Cell Biol. 120: 235-243.

Thiede, M.A. and G.A. Rodan. 1988. Expression of a calciummobilizing parathyroid hormone-like peptide in lactating mammary tissue. Science 242: 278-280.

Tybulewicz, V.L.J., C.E. Crawford, P.K. Jackson, R.T. Bronson, and R.C. Mulligan. 1991. Neonatal lethality and lymphopenia in mice with a homozygous disruption of the c-abl protooncogene. Cell 65: 1153-1163.

Vandenberg, P., J.S. Khillan, D.J. Prockop, H. Helminen, S. Kontusaari, and L. Ala-Kokko. 1991. Expression of a partially deleted gene of human type II procollagen (COL2Al) in transgenic mice produces a chodrodysplasia. Proc. Natl. Acad. Sci, 88: 7640-7644.

Yasuda, T., D. Banville, S.A. Rabbani, G.N. Hendy, and D. Goltzman. 1989. Rat parathyroid hormone-like peptide: Comparison with the human homologue and expression in malignant and normal tissue. Mol. Endocrinol. 3: 518-525.
Zijlstra, M., E. Li, F. Sajiadi, S. Subramani, and R. Jaenisch. 1989. Germ-line transmission of a disrupted $\beta_{2}$-microglobulin gene produced by homologous recombination in embryonic stem cells. Nature 342: 435-438. 


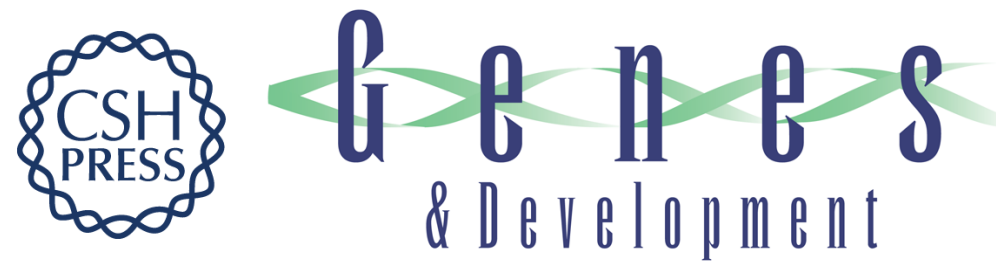

\section{Lethal skeletal dysplasia from targeted disruption of the parathyroid hormone-related peptide gene.}

A C Karaplis, A Luz, J Glowacki, et al.

Genes Dev. 1994, 8:

Access the most recent version at doi:10.1101/gad.8.3.277

References This article cites 42 articles, 16 of which can be accessed free at:

http://genesdev.cshlp.org/content/8/3/277.full.html\#ref-list-1

License

Email Alerting

Service

Receive free email alerts when new articles cite this article - sign up in the box at the top right corner of the article or click here.

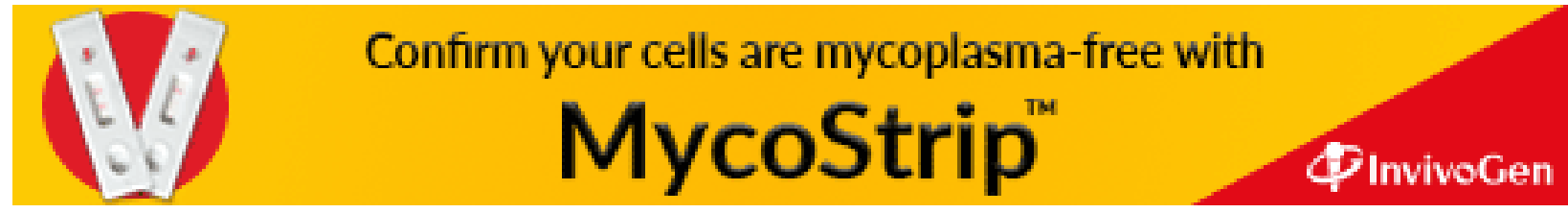

